\title{
Water Supply Portfolio Planning and Policy Evaluation under Climate Change: A Case Study of Central Taiwan
}

\author{
Yen-Chen Huang ${ }^{1}$, Chien-Ming Lee ${ }^{2, *}$ and Yue-Rong Hong ${ }^{2,3}$ \\ 1 LotSoar Consultants Inc., Taipei 106, Taiwan; ychuang1225@gmail.com \\ 2 Institute of Natural Resource Management, National Taipei University, Taipei 23741, Taiwan; \\ greenart1010@gmail.com \\ 3 Department of Information Management, National Taiwan University of Science and Technology, \\ Taipei 106, Taiwan \\ * Correspondence: cmlee@mail.ntpu.edu.tw; Tel.: +886-2-8674-1111 (ext. 67335); Fax: +886-2-86716313
}

check for updates

Citation: Huang, Y.-C.; Lee, C.-M.; Hong, Y.-R. Water Supply Portfolio Planning and Policy Evaluation under Climate Change: A Case Study of Central Taiwan. Water 2021, 13, 567. https://doi.org/10.3390/ w13040567

Academic Editor: Ashok Sharma

Received: 16 December 2020

Accepted: 17 February 2021

Published: 23 February 2021

Publisher's Note: MDPI stays neutral with regard to jurisdictional claims in published maps and institutional affiliations.

Copyright: (c) 2021 by the authors. Licensee MDPI, Basel, Switzerland. This article is an open access article distributed under the terms and conditions of the Creative Commons Attribution (CC BY) license (https:// creativecommons.org/licenses/by/ $4.0 /)$.

\begin{abstract}
The present study examines the optimal water supply portfolio under the impact of climate change constructed by the authors previously. It incorporates feasibility planning for water supply projects, assesses a feasible water supply portfolio for central Taiwan, and uses the shadow price method to assess the rationality of the compensation policy for transferring agricultural water to ensure water supply security for the industrial sector. The study finds that Changhua and Yunlin have the highest per-unit costs of raw water, and the Nantou region has the highest carbon emission coefficient (carbon footprint) per unit of water produced. The cumulative value (2021-2031) of the water resources policy to reallocate agricultural water to achieve water supply security is about TWD 15.904-31.13 billion. The shadow price of industrial water is about TWD 40.18/cubic meter. Therefore, a compensation price for agricultural water transfer of less than TWD 40.18/cubic meter represents a rational policy.
\end{abstract}

Keywords: climate change; water supply portfolio; shadow price; water supply security; policy value

\section{Introduction}

Enhancing water supply security has become the most important governance challenge for water authorities in various countries in response to climate change (Intergovernmental Panel on Climate Change (Intergovernmental Panel on Climate Change, IPCC), 2014). IPCC (2014) points out that strengthening adaptation measures, especially in scientific forecasting, risk management, and impact assessment of surface water supply, at the same time as strengthening the conservation of groundwater resources to meet future demand for groundwater extraction will be priority policy strategies for water resource managers around the world [1]. The central region of Taiwan (including Miaoli, Taichung, Nantou, Yunlin, and Changhua) needs to strengthen the water use environment and improve water use efficiency. Central Taiwan is a region that is vulnerable to climate change, particularly as the over-reliance on groundwater by water users has led to severe subsidence. Aside from existing major water supply facilities, there are a number of water supply facilities under construction, including the Joint Water Source Utilization Project of the Da'an and Dajia Rivers, the Niaozuitan Artificial Lake, and reclaimed water projects. To ensure that water supply facility projects are properly implemented, in addition to technical considerations such as current supply and demand, factors such as water supply value, environmental impact, affordability, and social acceptability should be integrated into the assessment for medium to long-term planning (2031). The Water Resources Agency has set a cap on total water supply for 20 billion cubic meters for 2031.

The industry has had high added-value. In the face of extreme climate, in order to ensure water supply security for the industry, the government transfers reallocated water from agriculture. Therefore, evaluating the costs of water resource scarcity for agriculture 
(or the value of secure water supply) has become an important basis for evaluating the rationality of the government's agricultural water transfer and compensation policies. The compensation fee for the transfer of allocation water is currently approximately TWD 20/cubic meter.

The literature on the impact of climate change on water supply security can be divided into three types: (1) the impact of climate change on water supply [2,3], discussing the impact on changes in rainfall under different warming scenarios on water supply security; (2) water supply adaptation planning and empirical research in response to climate change [4-6], establishing water supply management plans for specific regions in response to climate change; and (3) applying hydro-economic models to water supply management strategies [7-9] to explore the most appropriate (minimum cost or maximum benefit) water supply management strategy under different economic and hydrological conditions. Huang and Lee [10] pioneered the application of the hydro-economic model to establish a climate-resilient water supply portfolio, including the dimensions of reliability, economic feasibility, affordability, environmentally friendly, and social acceptability. It can also capture the cost of water supply infrastructure in different periods and provide a reference for medium and long-term water resources infrastructure planning. However, the above model does not take into account water resources infrastructure in policy planning and is, therefore, likely to result in a decoupling of optimal planning and feasible planning.

The shadow price is used in traditional literature as a measure of the price for something that is not normally priced in the market. In the case of water supply, the so-called shadow price refers to the marginal contribution to the objective function (usually measured in terms of net social benefits) from not using a single unit of water. In the optimal situation, the shadow price should be equal to the user cost of the water resource [11]. Based on Harrington's (1987) definition, the shadow price consists of use value and retention value. Use value refers to the operation and maintenance cost of the water supply system; retention value is the value to future generation's water resource use from reducing (or retaining) one unit of water resources in the current generation. The unit cost measurement will vary between firms and the government. The main reason is that the externalities of water supply (e.g., costs of environmental damage costs) are not considered in the decision-making models of firms. In contrast, the government takes overall social benefits as the starting point and, therefore, takes into account external costs. Therefore, if we take the government decision-making model as an example, the measured shadow price will include the current value of the future saving in extraction costs and environmental costs of extracting one unit less of water now, reflecting higher user costs. However, from the perspective of firms, the shadow value of water resources reflects the difference between its marginal benefits and marginal costs. Since Hotelling [12] proposed his theory on the optimal extraction of exhaustible resources, many economists [13-26] have applied shadow pricing to water supply management and pricing. Since the shadow price represents the social value of not using a single unit of water or the social cost (or shadow cost) of depleting a single unit of water, the shadow price can be used as a basis for assessing the genuine value of the water supply (or the cost of water shortage). The shadow price of water resources is not easy to measure. The main influence factors include: (1) Hydrological conditions: permeability coefficient for groundwater recharge, delay time for groundwater discharge, area of aquifers, storage coefficient of aquifers, and the natural recharge rate of groundwater; (2) Cost of Water extraction: marginal pumping costs for groundwater according to hydraulic head; (3) Market behavior: groundwater demand parameters, groundwater pumping capacity, and water intake; (4) Social benefits and costs: marginal benefits of water extraction and marginal costs of water extraction.

The impact of climate change on Taiwan has increased the risk of water scarcity by increasing variability between wet and dry periods and reducing the intervals between dry years. Therefore, the present study refers to the water supply portfolio model for climate resilience developed by Huang and Lee (2019), using central Taiwan as a case study. The study considers hydrological and economic characteristics of different water sources and 
the government's forward-looking infrastructure development program for water supply infrastructure to put forward a feasible water supply portfolio to achieve water supply security. The shadow price of water resources is then applied to evaluate the value of water supply security (or the cost of water shortage) for the industry as a basis for a rational compensation policy for the transfer of agricultural water supply to industry. The present study is organized as follows: the second section is planning the optimal water resources portfolio for central Taiwan; the third section is the assessment of the value of the water supply security policy; the fourth section is the conclusion and recommendations.

\section{Feasible Water Supply Portfolio for Water Supply Security in Central Taiwan}

In this section the model development, derivation of the solution, and the application to the water supply planning in central Taiwan are described as below. The flow chart is shown in Figure 1.

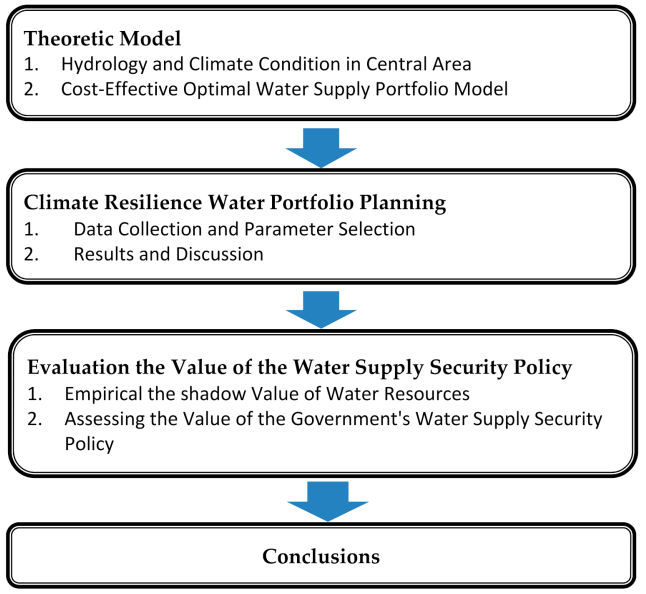

Figure 1. Determination of cost-effective water supply portfolio for water supply security in central Taiwan.

\subsection{Theoretic Model}

\subsubsection{Hydrology and Climate Condition in Central Area}

Currently, water supply in central Taiwan mainly consists of surface water (lakes, reservoirs, dams) and groundwater. However, according to the plans of the Water Resources Agency, future water supply will include reclaimed water. Therefore, the present study includes three types of water resources. The basic parameters for the model are as follows:

1. Water supply target: The target year of 2031 is the final year of the model.

2. Water supply recipients: Given the characteristics of agriculture water supply, agriculture water supply is first deducted from potential natural water resource. Therefore, the study evaluates the optimal mixed for the remaining water supply based on public water resource (domestic and industrial).

3. Water supply scenarios: Due to the significant difference between the wet and dry periods for surface water in central Taiwan, the water supply portfolios are divided into two scenarios (wet and dry).

4. Water supply type: Diversified development (investment) to ensure stable water supply, including surface water (lakes and reservoirs, weirs, and artificial lakes), groundwater, and reclaimed water. If, due to the influence of wet or dry periods or climate change, the potential supply of natural water resources cannot meet demand, responses include the development of water resources (groundwater, desalinated seawater) or the transfer of agricultural water.

5. Water supply security: Ensure that the annual water supply is not less that the planned annual water demand. In addition, the amount of surface water and groundwater 
that can be extracted is affected by climate change, which is reflected in water supply security.

6. Water supply characteristics: Consider intermittency costs, which are reflected in water supply stability.

7. Impact of climate change: In central Taiwan, surface water is most affected by climate change. Therefore, in this study, we apply a worst-case to simulate the reduction in surface water runoff caused by climate change.

8. Environmental cost of water supply: For the environmental cost of water production (resource depletion and environmental degradation), carbon emissions offer the most complete data currently available. Therefore, this study uses carbon emissions per unit of water produced to represent the environmental impact, which mainly reflects the cost of reducing the carbon footprint. In other words, the greater the carbon emissions per unit of water produced, the higher the environmental cost.

\subsubsection{Cost-Effective Optimal Water Supply Portfolio Model}

This study refers to [1] to establish a cost-effective water supply portfolio model as follows: Cost-effectiveness is the ability to achieve environmental or economic goals at the lowest possible cost.

$$
\begin{gathered}
\text { Min } Z=\int_{0}^{T}\left(\sum_{i=1}^{3} T C_{i t}\right) e^{-\rho t} d t \\
T C_{i t}=\left(C_{i t}+\varphi_{i}\right) \times Q_{i t}+P_{A i} A_{i}+P_{e i} E_{i}(\forall 1 \sim 3) \\
C_{i t}=\left(P_{I i t} I_{i t}+P_{F i i} F_{i t}+\bar{O}_{i}\right) / Q_{i t}(\forall 1 \sim 3) \\
\dot{K}_{i t}=I_{i t}-\delta_{i} K_{i t}(\forall 1 \sim 3) \\
\sum_{i=1}^{3} Q_{i t} \geq \bar{Q}_{t} \\
\sum_{t=0}^{T} \sum_{i=1}^{3} E_{i t} \leq \bar{E}_{T}
\end{gathered}
$$

where $T C_{i t}$ is the total water production cost for water supply type $i$ for period $t$ ( 1 for surface water, 2 for groundwater, 3 for reclaimed water). Equation (1) is the objective function reflecting the affordability of the water supply portfolio; $C_{i t}$ is the average unit cost for water production, which is equal to the sum of the water supply facility investment costs $\left(P_{I i t} I_{i t}\right)$, the raw water input costs $\left(P_{\text {Fit }} F_{i t}\right)$, and operating costs $\left(\bar{O}_{i}\right)$ (assumed to be fixed), divided by the volume of the water produced $\left(Q_{i t}\right) ; P_{I i t}$ is the unit investment cost, $I_{i t}$ is the amount of investment in water supply facilities; $\phi_{i t}$ is the intermittent cost of water supply, reflecting the instability of the water supply. If low rainfall due to climate change means insufficient surface water/groundwater for use, so additional water resources (such as transporting water from other regions or short-term emergency increases in water supply from desalination plants) are needed to meet demand, generating additional costs. The present study assumes that emerging water resources (such as reclaimed water) are very stable, so there is no intermittent cost, i.e., $\varphi_{3}=0$. The environmental cost of water production is represented by the $\operatorname{cost}\left(P_{A i} A_{i t}\right)$ of carbon dioxide abatement, equivalent to the product of the abatement price $\left(P_{A i}\right)$ and the abatement volume $\left(A_{i t}\right)$. The cost of carbon dioxide emissions $\left(\mathrm{CO}_{2}\right)$ is equal to the product of carbon price $\left(P_{e i}\right)$ and net $\mathrm{CO}_{2}$ emissions $\left(E_{i t}\right)$, reflecting the environmental cost. The present study assumes that the carbon price $\left(P_{e i}\right)$, raw water price $\left(P_{F i}\right)$, and abatement price $\left(P_{A i}\right)$ are exogenously fixed. $\dot{K}_{i t}$ is the water supply capital stock for period $t \delta_{t}$ is the capital depreciation rate for type $i$ water supply (assumed to be fixed).

Assuming that the aforementioned water production $\left(Q_{i t}\right)$, as well as being a function of raw water input $\left(F_{i t}\right)$, is a function of the water supply capital stock $\left(K_{i t}\right)$, i.e., $Q_{i t}\left(F_{i t}, K_{i t}\right)$ and the quasi-concave function of the capital stock. i.e., $\partial Q_{i t} / \partial K_{i t} \geq 0$ and $\partial^{2} Q_{i t} / \partial K_{i t}^{2} \leq 0$. 
$\bar{Q}_{t}$ is the planned water demand for each period for the economy and society of central Taiwan. Equation (5) states the total water production from the three types of water source in period $t$ should not be less than the water demand in period $t$ in order to meet the water demand for water in the current period, reflecting the reliability of the water supply system (or water supply security). $\bar{E}_{T}$ is the carbon dioxide emissions cap for the water resources sector up to the target year 2031. Therefore, Equation (6) is a greenhouse gas emission target for the water resources sector, reflecting environmental friendliness.

\subsection{Optimal Portfolio Equation}

The model above produces the optimal combination of the three types of water resources as follows (for detailed derivation, see [1] and Appendix A):

$$
\begin{aligned}
\frac{Q_{1}}{K_{1}}=\omega_{1} k_{1}^{1-\gamma}= & {\left[\left(1-\alpha_{1}\right)(1-\mu)\right]\left(\frac{1-\gamma}{\gamma}\right)^{1-\gamma}\left\{\frac{P_{I 1}\left(\delta_{1}-\rho\right)}{P_{F 1}+P_{A 1} e_{01}}\right\}^{1-\gamma} } \\
\frac{Q_{2}}{K_{2}}=\omega_{2} k_{2}^{1-\gamma}= & {\left[\left(1-\alpha_{2}\right)(1-\eta)\right]\left(\frac{1-\gamma}{\gamma}\right)^{1-\gamma}\left\{\frac{P_{I 2}\left(\delta_{2}-\rho\right)}{P_{F 2}+P_{A 2} e_{02}}\right\}^{1-\gamma} } \\
\frac{Q_{3}}{K_{3}} & =\omega_{3} k_{3}^{1-\gamma}\left(\frac{1-\gamma}{\gamma}\right)^{1-\gamma}\left[\frac{P_{I 3}\left(\delta_{3}-\rho\right)}{P_{F 3}+P_{A 3} e_{03}}\right]^{1-\gamma}
\end{aligned}
$$

In the present study, Equation (7) to Equation (9) represent the basis for the water supply portfolio in the target year, which is affected by the technical parameters of water resources $(\gamma)$, the decline in the total volume that can be extracted due to the impact of climate change $\left(\alpha_{i}\right)$, ecological base flow ratio $(\mu)$, groundwater recharge ratio $(\eta)$. raw water input costs $\left(P_{F_{i}}\right)$, net depreciation cost of investment in water supply facilities $\left(P_{I i}\left(\delta_{i}-\rho\right)\right.$, emission abatement $\operatorname{costs}\left(P_{A i}\right)$, and the carbon emission coefficient for raw water $\left(e_{0 i}\right)$.

\subsection{Climate Resilence Water Supply Portfolio Planning for Central Taiwan}

\subsubsection{Data Collection and Parameter Selection for Each Sub-Area}

In order to estimate the optimal water supply portfolio for each area of central Taiwan, the present study collected the data required by the model and set possible scenarios for some of the parameters. The technical parameter for water source $(\gamma)$ was assumed to be 0.5 [1] and the other parameters are described below:

1. Study period

The study period ends in 2031. In order to understand the possible changes in water resource allocation over time, the years 2021 and 2026 are used as the study years.

\section{Water supply targets}

The annual water supply capacity in each target year for each area in this study is shown in Table 1. The public water demand in each target year in Miaoli is 275,000, 281,000, and 281,000 cubic meters/day, respectively. The public water demand in each target year in Taichung is 1,501,000, 1,552,000, and 1,572,000 cubic meters/day, respectively. The annual public water demand in each target year in Nantou is $164,000,162,000$, and 160,000 cubic meters/day, respectively. The public water demand in each target year in Yunlin and Changhua is 636,000, 641,000, and 637,000 cubic meters/day, respectively. Setting ratios for ecological base flow and groundwater recharge: 
Table 1. Public Water Demand in Each Target Year by Area in Central Taiwan.

\begin{tabular}{|c|c|c|c|c|c|c|c|}
\hline \multirow[b]{2}{*}{ Area } & \multirow[b]{2}{*}{ Water Type } & \multicolumn{2}{|c|}{2021} & \multicolumn{2}{|c|}{2026} & \multicolumn{2}{|c|}{2031} \\
\hline & & $\begin{array}{c}\text { Water } \\
\text { Consumption }\end{array}$ & Total & $\begin{array}{c}\text { Water } \\
\text { Consumption }\end{array}$ & Total & $\begin{array}{c}\text { Water } \\
\text { Consumption }\end{array}$ & Total \\
\hline \multirow[t]{2}{*}{ Miaoli } & $\begin{array}{l}\text { Domestic } \\
\text { water use }\end{array}$ & 12.72 & \multirow[t]{2}{*}{27.50} & 12.73 & \multirow[t]{2}{*}{28.10} & 12.66 & \multirow[t]{2}{*}{28.10} \\
\hline & $\begin{array}{l}\text { Industrial } \\
\text { water use }\end{array}$ & 14.78 & & 15.37 & & 15.44 & \\
\hline \multirow[t]{2}{*}{ Taichung Area } & $\begin{array}{l}\text { Domestic } \\
\text { water use }\end{array}$ & 98.73 & \multirow[t]{2}{*}{150.10} & 98.43 & \multirow[t]{2}{*}{155.20} & 98.29 & \multirow[t]{2}{*}{157.20} \\
\hline & $\begin{array}{l}\text { Industrial } \\
\text { water use }\end{array}$ & 51.37 & & 56.77 & & 58.91 & \\
\hline \multirow[t]{2}{*}{ Nantou Area } & $\begin{array}{l}\text { Domestic } \\
\text { water use }\end{array}$ & 14.25 & \multirow[t]{2}{*}{16.40} & 13.96 & \multirow[t]{2}{*}{16.20} & 13.70 & \multirow[t]{2}{*}{16.00} \\
\hline & $\begin{array}{l}\text { Industrial } \\
\text { water use }\end{array}$ & 2.15 & & 2.24 & & 2.30 & \\
\hline \multirow{2}{*}{$\begin{array}{c}\text { Changhua and } \\
\text { Yunlin Area }\end{array}$} & $\begin{array}{l}\text { Domestic } \\
\text { water use }\end{array}$ & 54.06 & \multirow[t]{2}{*}{63.60} & 53.67 & \multirow[t]{2}{*}{64.10} & 53.16 & \multirow[t]{2}{*}{63.70} \\
\hline & $\begin{array}{l}\text { Industrial } \\
\text { water use }\end{array}$ & 9.54 & & 10.43 & & 10.54 & \\
\hline
\end{tabular}

Unit: 10,000 cubic meters/day. Source: [27], compiled by this study.

3. Ecological base flow and groundwater recharge ratios

The ratios for the ecological base flow of rivers and groundwater recharge for each area in central Taiwan are shown in Table 2.

Table 2. Ratios for the Ecological Base Flow of Rivers and Groundwater Recharge by Area in Central Taiwan.

\begin{tabular}{|c|c|c|c|}
\hline Area & Water Resource & Ecological Base Flow Ratio & $\begin{array}{c}\text { Groundwater Recharge } \\
\text { Ratio }\end{array}$ \\
\hline \multirow{3}{*}{ Miaoli } & Zhonggang River & $4.75 \%$ & - \\
\hline & Houlong River & $3.35 \%$ & - \\
\hline & Groundwater 1 & - & $0 \%$ \\
\hline \multirow{3}{*}{ Taichung Area } & Da'an River & $7.33 \%$ & - \\
\hline & Dajia River & $12.39 \%$ & - \\
\hline & Groundwater 1 & - & $0 \%$ \\
\hline \multirow{2}{*}{ Nantou Area } & Wu River & $8.31 \%$ & - \\
\hline & Groundwater 1 & - & $0 \%$ \\
\hline \multirow[b]{2}{*}{ Changhua and Yunlin Area } & Zhuoshui River & $7.62 \%$ & - \\
\hline & Groundwater 2 & - & $\begin{array}{l}\text { 2021: } 43.49 \% \\
\text { 2026: } 86.05 \% \\
2031: 86.05 \%\end{array}$ \\
\hline
\end{tabular}

${ }^{1}$ Set to zero because the water intake of groundwater facilities is less than the potential energy of groundwater, and there are no problems such as excessive intake or subsidence.; ' Work with the "Specific Solution to Long-term Land Subsidence in Yunlin and Changhua Area" to reduce water pumping every year in order to achieve the goal of groundwater conservation. Source: [27], compiled by this study.

4. Unit raw water input cost $\left(P_{F i}\right)$ and unit net depreciation cost $\left(P_{I i}\left(\delta_{i}-\rho\right)\right)$

This study collected and aggregated the unit raw water input cost, unit net depreciation cost, and data sources for water supply facilities in each area, as shown in Table 3. From the data, the unit cost of raw water is lower for lakes and reservoirs and weirs) and higher for reclaimed water and desalinated seawater. In addition, the unit cost for surface water supply facilities such as the Tianhuahu Reservoir and Niaozuitan Artificial Lake is higher than that of existing surface water facilities. 
Table 3. Raw Water Input and Net Depreciation Cost of Water Supply Facilities by Area in Central Taiwan.

\begin{tabular}{|c|c|c|c|c|}
\hline Area & Water Supply Facility & $\begin{array}{l}\text { Unit Raw Water Input } \\
\text { Cost (t/TWD) }\end{array}$ & $\begin{array}{l}\text { Unit Net Depreciation } \\
\text { Cost (t/TWD) }\end{array}$ & Source \\
\hline \multirow{4}{*}{ Miaoli } & Yongheshan Reservoir & 8.30 & 0.0545 & {$[28,29]$} \\
\hline & Mingde Reservoir & 5.89 & 0.0325 & {$[28,29]$} \\
\hline & Tianhuahu Reservoir & 11.00 & 0.1001 & [28-30] \\
\hline & Groundwater wells & 7.95 & 0.1578 & {$[31,32]$} \\
\hline \multirow{5}{*}{ Taichung Area } & Liyutan Reservoir & 4.64 & 0.0212 & {$[28,29]$} \\
\hline & $\begin{array}{c}\text { Shigang Dam (Fengyuan } \\
\text { Water Treatment Plant) }\end{array}$ & 3.33 & 0.0093 & {$[28,29]$} \\
\hline & $\begin{array}{l}\text { Shigang Dam (Joint Water } \\
\text { Source Utilization Project of } \\
\text { Da'an and Dajia Rivers) }\end{array}$ & 7.58 & 0.0835 & [33] \\
\hline & Groundwater wells & 7.95 & 0.1578 & {$[31,32]$} \\
\hline & $\begin{array}{l}\text { Futian Water Resource } \\
\text { Recycling Center }\end{array}$ & 11.40 & 0.3078 & {$[34]$} \\
\hline \multirow{2}{*}{ Nantou Area } & Niaozuitan Artificial Lake & 12.02 & 0.1094 & {$[28,35]$} \\
\hline & Groundwater wells & 7.95 & 0.1578 & {$[31,32]$} \\
\hline \multirow{4}{*}{ Changhua and Yunlin Area } & $\begin{array}{c}\text { Joint Water Source } \\
\text { Utilization Project of Jiji Weir } \\
\text { and Hushan Reservoir }\end{array}$ & 11.60 & 0.1056 & [36-38] \\
\hline & Niaozuitan Artificial Lake & 12.02 & 0.1094 & {$[28,35]$} \\
\hline & Groundwater wells & 7.95 & 0.1578 & {$[31,32]$} \\
\hline & $\begin{array}{l}\text { Futian Water Resource } \\
\text { Recycling Center }\end{array}$ & 11.40 & 0.3078 & {$[34]$} \\
\hline New water resource & Seawater desalination & 41.47 & 0.5305 & {$[28,32]$} \\
\hline
\end{tabular}

Compiled by this study.

5. Carbon emission targets, carbon emission coefficient per unit of water produced $\left(e_{0 i}\right)$, and carbon abatement cost per unit

Taiwan's Intended Nationally Determined Contribution (INDC) (Environmental Protection Agency, 2015) mitigation measures include seven major sectors: energy, industry, housing, services, transportation, agriculture, and waste. Water resources are not included and there is no specific emission reduction target. In the present study, the principle of no increase in future carbon emissions is used as the basis for setting carbon emission targets for water resources. The study collects relevant reports from previous years and summarizes the carbon emission coefficient per unit of water produced for water supply facilities in each area in Table 4. For emissions mitigation, the present study assumes this is carried out by purchasing carbon rights. The cost per ton of $\mathrm{CO}_{2}$ is set at TWD 150 (approximately EUR 5/ton of $\mathrm{CO}_{2} \mathrm{e}$ ) based on the average carbon price in the European Union in 2018 and substituted into the optimal supply portfolio model. As can be seen from Table 4, surface water facilities have the lowest carbon emission coefficient per unit of water produced, followed by groundwater and reclaimed water, with desalinated seawater the highest. 
Table 4. Carbon Emissions per cubic meters of Water Produced and Carbon Abatement Cost per ton.

\begin{tabular}{|c|c|c|c|c|}
\hline Area & Water Supply Facility & $\begin{array}{c}\text { Carbon Emissions Coefficient } \\
\text { per Unit of Water Produced } \\
\left(\mathrm{kgCO}_{2 \mathrm{e}} / \text { Cubic Meters }\right)\end{array}$ & $\begin{array}{l}\text { Carbon Abatement } \\
\text { Cost per Unit } \\
\left(\mathrm{TWD} / \text { tonCO } \mathrm{CO}_{2 \mathrm{e}}\right)\end{array}$ & Source: \\
\hline \multirow{4}{*}{ Miaoli Area } & Yongheshan Reservoir & 0.0050 & \multirow{16}{*}{150} & [39] \\
\hline & Mingde Reservoir & 0.0352 & & {$[39,40]$} \\
\hline & Tianhuahu Reservoir & 0.0651 & & {$[40,41]$} \\
\hline & Groundwater wells & 0.2995 & & {$[31,32]$} \\
\hline \multirow{5}{*}{ Taichung Area } & Liyutan Reservoir & 0.0029 & & [39] \\
\hline & $\begin{array}{l}\text { Shigang Dam } \\
\text { (Fengyuan Water } \\
\text { Treatment Plant) }\end{array}$ & 0.0024 & & {$[39,41]$} \\
\hline & $\begin{array}{c}\text { Shigang Dam (Joint } \\
\text { Water Source } \\
\text { Utilization Project of } \\
\text { Da'an and Dajia Rivers) }\end{array}$ & 0.0240 & & {$[33,41]$} \\
\hline & Groundwater wells & 0.2995 & & {$[31,32]$} \\
\hline & $\begin{array}{l}\text { Futian Water Resource } \\
\text { Recycling Center }\end{array}$ & 0.9500 & & {$[34,39]$} \\
\hline \multirow{6}{*}{ Changhua and Yunlin Area } & $\begin{array}{c}\text { Niaozuitan Artificial } \\
\text { Lake }\end{array}$ & 0.0093 & & [42] \\
\hline & Groundwater wells & 0.2995 & & {$[31,32]$} \\
\hline & $\begin{array}{l}\text { Joint Water Source } \\
\text { Utilization Project of Jiji } \\
\text { Weir and Hushan } \\
\text { Reservoir }\end{array}$ & 0.0278 & & {$[36,38]$} \\
\hline & $\begin{array}{c}\text { Niaozuitan Artificial } \\
\text { Lake }\end{array}$ & 0.0093 & & [42] \\
\hline & Groundwater wells & 0.2995 & & {$[31,32]$} \\
\hline & $\begin{array}{l}\text { Futian Water Resource } \\
\text { Recycling Center }\end{array}$ & 0.9500 & & {$[34,39]$} \\
\hline $\begin{array}{c}\text { New } \\
\text { Water Resource }\end{array}$ & Seawater desalination & 2.2860 & & {$[28,32]$} \\
\hline
\end{tabular}

6. Climate change scenario

The worst-case scenario for the impact of climate change on surface water is shown in Table 5.

Table 5. Ratio of Reduction in Surface Water in Each Area of Central Taiwan Due to Climate Change.

\begin{tabular}{cccc}
\hline Target Year & $\mathbf{2 0 2 1}$ & $\mathbf{2 0 2 6}$ & $\mathbf{2 0 3 1}$ \\
\hline Zhonggang River & $0.28 \%$ & $0.56 \%$ & $0.85 \%$ \\
\hline Houlong River & $1.65 \%$ & $3.30 \%$ & $4.95 \%$ \\
\hline Da'an River & $1.31 \%$ & $2.61 \%$ & $3.92 \%$ \\
\hline Dajia River & $2.35 \%$ & $4.70 \%$ & $7.04 \%$ \\
\hline Wu River & $0.86 \%$ & $1.72 \%$ & $2.58 \%$ \\
\hline Zhuoshui River & $4.00 \%$ & $8.00 \%$ & $12.00 \%$ \\
\hline & Compiled by this study. & &
\end{tabular}




\subsubsection{Results Analysis}

With the aforementioned model parameter settings, we can calculate the water supply portfolio to ensure water security during dry periods when faced with extreme climate for each area of central Taiwan, as shown in Table 6 below. The study classifies the scenarios for each area into four types. Wet year without climate change (Scenario 1), dry year without climate change (Scenario 2), wet year under climate change (Scenario 3), and dry year under climate change (Scenario 4). However, due to space limitations, only the results of Scenario 4 are presented. Readers interested in the other three scenarios can obtain them from the corresponding author. The details are as follows.

Table 6. Water Supply Portfolio for Water Supply Security in Central Taiwan under a Dry Scenario.

\begin{tabular}{|c|c|c|c|c|c|}
\hline \multicolumn{3}{|c|}{ Target year } & 2021 & 2026 & 2031 \\
\hline \multicolumn{3}{|c|}{ Public water consumption } & 27.5 & 28.1 & 28.1 \\
\hline \multicolumn{3}{|c|}{ Auxiliary water } & -10.0 & -10.0 & -7.0 \\
\hline \multirow{7}{*}{ Miaoli Area } & \multirow{5}{*}{ Water supply ratio } & Yongheshan Reservoir & $9.7(55.43 \%)$ & $9.7(53.59 \%)$ & $9.7(27.64 \%)$ \\
\hline & & Mingde Reservoir & $2.5(14.29 \%)$ & $2.5(13.81 \%)$ & $2.5(7.12 \%)$ \\
\hline & & Tianhuahu Reservoir & $0(0.00 \%)$ & $0(0.00 \%)$ & $19.4(55.27 \%)$ \\
\hline & & Groundwater wells & $3.5(20.00 \%)$ & $3.5(19.34 \%)$ & $3.5(9.97 \%)$ \\
\hline & & $\begin{array}{l}\text { Agricultural water use } \\
\text { efficiency improvement }\end{array}$ & $1.8(10.29 \%)$ & $2.4(13.26 \%)$ & $0(0.00 \%)$ \\
\hline & \multicolumn{2}{|c|}{ Raw water cost per unit (TWD/ton) } & 8.61 & 8.83 & 9.59 \\
\hline & \multicolumn{2}{|c|}{$\begin{array}{l}\text { Carbon emissions per unit of water } \\
\text { produced }(\mathrm{kg} / \mathrm{CO} 2 \mathrm{e} / \mathrm{m} 3)\end{array}$} & 0.0340 & 0.0329 & 0.0349 \\
\hline \multirow{8}{*}{ Taichung Area } & \multirow{6}{*}{ Water supply ratio } & Liyutan Reservoir & $62.0(36.88 \%)$ & $62.0(35.80 \%)$ & $62.0(37.53 \%)$ \\
\hline & & $\begin{array}{l}\text { Shigang Dam (Fengyuan } \\
\text { Water Treatment Plant) }\end{array}$ & $75.0(44.62 \%)$ & $62.55(38.42 \%)$ & $73.0(44.19 \%)$ \\
\hline & & $\begin{array}{l}\text { Shigang Dam (Joint Water } \\
\text { Source Utilization Project of } \\
\text { Da'an and Dajia Rivers) }\end{array}$ & $0(0.00 \%)$ & $25.0(14.43 \%)$ & $7.45(4.51 \%)$ \\
\hline & & Groundwater wells & $10.0(5.95 \%)$ & $10.0(5.77 \%)$ & $10.0(6.05 \%)$ \\
\hline & & $\begin{array}{l}\text { Futian Water Resource } \\
\text { Recycling Center }\end{array}$ & $0(0.00 \%)$ & $9.65(5.57 \%)$ & $10.0(6.05 \%)$ \\
\hline & & $\begin{array}{l}\text { Agricultural water use } \\
\text { efficiency improvement }\end{array}$ & $21.1(12.55 \%)$ & $0(0.00 \%)$ & $2.75(1.66 \%)$ \\
\hline & \multicolumn{2}{|c|}{ Raw water cost per unit (TWD/ton) } & 5.59 & 5.13 & 4.98 \\
\hline & \multicolumn{2}{|c|}{$\begin{array}{l}\text { Carbon emissions per unit of water produced } \\
\qquad(\mathrm{kg} / \mathrm{CO} 2 \mathrm{e} / \mathrm{m} 3)\end{array}$} & 0.0101 & 0.0378 & 0.0395 \\
\hline \multirow{4}{*}{ Nantou Area } & \multirow{2}{*}{ Water supply ratio } & Niaozuitan Artificial Lake & $0(0.00 \%)$ & $4.0(24.69 \%)$ & $4.0(25.00 \%)$ \\
\hline & & Groundwater wells & $16.4(100.00 \%)$ & $12.2(75.31 \%)$ & $12.0(75.00 \%)$ \\
\hline & \multicolumn{2}{|c|}{ Raw water cost per unit (TWD/ton) } & 7.95 & 8.96 & 8.97 \\
\hline & \multicolumn{2}{|c|}{$\begin{array}{l}\text { Carbon emissions per unit of water produced } \\
\qquad(\mathrm{kg} / \mathrm{CO} 2 \mathrm{e} / \mathrm{m} 3)\end{array}$} & 0.1497 & 0.1134 & 0.1129 \\
\hline
\end{tabular}


Table 6. Cont.

\begin{tabular}{|c|c|c|c|c|c|}
\hline & Target year & & 2021 & 2026 & 2031 \\
\hline \multirow{7}{*}{$\begin{array}{c}\text { Yunlin and } \\
\text { Changhua Area }\end{array}$} & \multirow{5}{*}{ Water supply ratio } & $\begin{array}{c}\text { Joint Water Source Utilization } \\
\text { Project of Jiji Weir and } \\
\text { Hushan Reservoir }\end{array}$ & $31.49(57.05 \%)$ & $37.35(67.06 \%)$ & $17.76(32.12 \%)$ \\
\hline & & Niaozuitan Artificial Lake & $0(0.00 \%)$ & $9.0(16.16 \%)$ & $21.0(37.97 \%)$ \\
\hline & & Groundwater wells & $23.71(42.95 \%)$ & $6.0(10.77 \%)$ & $6.0(10.85 \%)$ \\
\hline & & $\begin{array}{l}\text { Futian Water Resource } \\
\text { Recycling Center }\end{array}$ & $0(0.00 \%)$ & $3.35(6.01 \%)$ & $3.0(5.42 \%)$ \\
\hline & & $\begin{array}{l}\text { Agricultural water use } \\
\text { efficiency improvement }\end{array}$ & $0(0.00 \%)$ & $0(0.00 \%)$ & $7.54(13.63 \%)$ \\
\hline & \multicolumn{2}{|c|}{ Raw water cost per unit (TWD/ton) } & 10.03 & 11.26 & 11.86 \\
\hline & \multicolumn{2}{|c|}{$\begin{array}{l}\text { Carbon emissions per unit of water produced } \\
\qquad(\mathrm{kg} / \mathrm{CO} 2 \mathrm{e} / \mathrm{m} 3)\end{array}$} & 0.0722 & 0.0548 & 0.0484 \\
\hline
\end{tabular}

Unit: 10,000 cubic meters/day.

\section{Miaoli Area}

Due to the sufficient potential of natural water resources in the Miaoli area, the ability to supply water in dry years is limited only by the ability of facilities to supply water. Therefore, according to the model, in the target years 2021 and 2026, agricultural water use efficiency needs to be increased by 18,000 and 24,000 cubic meters/day, respectively. Water supply ratios for 2021: Yongheshan Reservoir 97,000 cubic meters/day (55.43\%), Mingde Reservoir 25,000 cubic meters/day (14.29\%), groundwater wells 35,000 cubic meters/day (20.00\%), agricultural water use efficiency improvement 18,000 cubic meters/day (10.29\%), unit raw water input cost approximately TWD 8.61/cubic meters, carbon emissions per unit of water produced $0.0340\left(\mathrm{~kg} / \mathrm{CO}_{2} \mathrm{e} /\right.$ cubic meters). Water supply ratios for 2026: Yongheshan Reservoir 97,000 cubic meters/day (53.59\%), Mingde Reservoir 25,000 cubic meters/day (13.81\%), groundwater wells 35,000 cubic meters/day (19.34\%), agricultural water use efficiency improvement 24,000 cubic meters/day (13.63\%), unit raw water input cost approximately TWD 8.83/ cubic meters, carbon emissions per unit of water produced 0.0329 ( kg/ $\mathrm{CO}_{2} \mathrm{e} /$ cubic meters). Water supply ratios for 2031: Yongheshan Reservoir 97,000 cubic meters/day (27.64\%), Mingde Reservoir 25,000 cubic meters/day (7.12\%), Tianhuahu Reservoir 194,000 cubic meters/day (55.27\%), groundwater wells 35,000 cubic meters/day (9.97\%), unit raw water input cost approximately NT9.59/cubic meters, carbon emissions per unit of water produced $0.0349\left(\mathrm{~kg} / \mathrm{CO}_{2} \mathrm{e} /\right.$ cubic meters). From the difference before and after the construction of the Tianhuahu Reservoir, we can see that after the Tianhuahu Reservoir starts supplying water, the costs of water supply rise. In order to minimize costs while ensuring sufficient supply potential, the other water supply facilities are used to the upper limit of their capacity, while intake from the Tianhuahu Reservoir is only $74.6 \%$ of capacity.

\section{Taichung Area}

Due to the influence of climate change in dry years, reduced river runoff means that industrial water use in 2021 requires an increase in agricultural water use efficiency of 27,500 tons/day. Water supply portfolio in Taichung Area: Liyutan Reservoir 622,000 cubic meters/day (37.53\%), Shigang Dam (Fengyuan Water Treatment Plant) 730,000 cubic meters/day (44.19\%), Shigang Dam (Joint Water Source Utilization Project of Da'an and Dajia Rivers) 74,500 cubic meters/day (4.51\%), groundwater wells 100,000 cubic meters /day (6.05\%), Futian Water Resource Recycling Center 100,000 cubic meters/day (6.05\%), agricultural water use efficiency improvement 27,500 cubic meters/day $(1.66 \%)$.

In 2021, due to the limited supply capacity of water supply facilities, agricultural water use efficiency needs to be increased by 21,000 cubic meters/day, making the unit raw water cost (TWD 5.59/ cubic meters) higher than in other target years. In 2026 and 
2031, the water supply capacity will increase due to the completion of the Shigang Dam (Joint Water Source Utilization Project of Da'an and Dajia Rivers), reducing the unit raw water cost (TWD 5.13/cubic meters and TWD 5.23/cubic meters). However, groundwater wells and the Futian Water Resource Recycling Center are relatively unaffected by climate change. Therefore, the calculation shows that water is supplied in full. Carbon emissions increase significantly due to a higher carbon emission coefficient for water produced at the Futian Water Resource Recycling Center.

\section{Nantou Area}

The Nantou Area has abundant water resources combined with low demand for public water. In dry years under climate change, the river runoff is sufficient to meet each type of water demand. Supply portfolio for 2021: Groundwater wells 164,000 cubic meters/day (100.00\%). Supply portfolio for 2026: Niaozuitan Artificial Lake 40,000 cubic meters/day $(24.69 \%)$, groundwater wells 122,000 cubic meters/day (75.31\%). Supply portfolio for 2031 : Niaozuitan Artificial Lake 40,000 cubic meters/day (25.00), groundwater wells 120,000 cubic meters/day (75.00\%). In the Nantou area, although the Niaozuitan Artificial Lake is surface water, due to its ample supply potential and low exposure to climate change, coupled with its low carbon emissions per unit of water produced (low environmental cost), when calculating the optimal water supply portfolio, it is set to supply water at full capacity.

\section{Yunlin and Changhua Area}

Water resources in the Yunlin and Changhua Area are relatively scarce compared to other areas. Due to ground subsidence caused by the long-term over-extraction of groundwater, it is necessary to reduce pumping to recharge aquifers. In addition, the Zhuoshui River is more affected by climate change. Therefore, for dry years under climate change, industrial water use must rely on improving the efficiency of agricultural water use. In 2021, the water resource supply mix portfolio is as follows: Joint Water Source Utilization Project of Jiji Weir and Hushan Reservoir 314,900 cubic meters/day (57.05\%), groundwater wells 237,100 cubic meters/day (42.95\%). In 2026, due to the start of the first stage of water supply from the Niaozuitan Artificial Lake (90,000 cubic meters/day), the water supply portfolio is: Joint Water Source Utilization Project of Jiji Weir and Hushan Reservoir 373,500 cubic meters/day (67.06\%), Niaozuitan Artificial Lake 90,000 cubic meters/day (16.16\%), groundwater wells 60,000 cubic meters/day (10.77\%), Futian Water Resource Recycling Center 33,500 cubic meters/day (6.01\%). In 2031, the water supply portfolio is: Joint Water Source Utilization Project of Jiji Weir and Hushan Reservoir 177,600 cubic meters/day (32.12\%), Niaozuitan Artificial Lake 210,000 cubic meters/day (37.97\%), groundwater wells 60,000 cubic meters/day (10.85\%), Futian Water Resource Recycling Center 30,000 cubic meters/day (5.42\%), agricultural water use efficiency improvement 75,400 cubic meters/day (13.63\%).

\subsection{Discussions}

From the above analysis, it can be seen that the water supply and demand varies considerably between different areas. The problems faced in the Taichung area and the Yunlin and Changhua are very different. The Taichung area is experiencing an increase in water demand, while the Yunlin and Changhua area suffers from a lack of water resources potential. Therefore, the planning of solutions requires a detailed comparison and evaluation. The main points of the assessment for different areas provided by the model proposed in this study are as follows:

1. The model can be applied to water supply planning in different areas to calculate the optimal supply portfolio according to the characteristics of each area. Therefore, in order to discuss individual cases (such as the use of the Jiji Weir), detailed information on the supply and demand situation in the area and the setting of the scenario to be evaluated can be substituted into the model for analysis. 
2. If there is a greater diversity of water supplies in an area, there will be more feasible water supply portfolios, indicating that the water supply in the area has greater climate resilience.

3. In the case of sufficient water supply potential, the model tends to deploy more low cost, low environmental impact (carbon footprint) water sources.

4. After setting the groundwater recharge ratio, if other water sources still have supply capacity, the model tends to reduce supply from groundwater.

5. The model can calculate the unit cost of water production according to the supply ratio of each water source. This can then be compared with the losses caused by the transfer of agricultural water as a basis for planning.

6. The model can calculate the environmental cost of each type of water supply. At present, the study uses carbon emissions as a proxy for environmental cost. In the future, if there are other quantifiable environmental costs (depletion of resources or impairment of environmental quality) associated with the use of water resources, they can also be included in the model.

\section{Evaluation the Value of the Water Supply Security Policy for the Industrial Sector}

\subsection{Empirical the Shadow Value of Water Resources}

The methodology for assessing the shadow price of water resources will vary with the study's subject matter, and have different economic meanings and assessment methods, for example: (1) Private water extraction (e.g., groundwater and river diversion), measured in terms of marginal user costs; (2) Paid water supply (e.g., tap water) is measured in terms of net marginal benefit (or value). Since this study is based on paid water supply, net marginal benefit is used to measure the shadow price of water in the industrial sector.

\subsubsection{Date Collection}

This study is based on data from 27 major industries ( 2 digits) and 837 specific sectors (4 digits) in the Factory Operation Census Report of the Ministry of Economic Affairs (2013), including 315,835 data points from firms over four years (2009, 2010, 2012, and 2013), to conduct a shadow price assessment for industrial water use. The regression analysis in the present study is limited to specific sectors (4 digits). Therefore, the present study compiled data for 837 specific sectors, including operating revenue (TWD, $1000 \mathrm{~s}$ ), employee salaries (TWD, $1000 \mathrm{~s}$ ), consumption of raw materials (TWD, $1000 \mathrm{~s}$ ), electricity consumption (TWD, $1000 \mathrm{~s}$ ), water consumption (cubic meters, $1000 \mathrm{~s}$ ), outsourcing expenditure (TWD, $1000 \mathrm{~s}$ ), depreciation and indirect taxes (TWD, $1000 \mathrm{~s}$ ), and operating expenses (TWD, $1000 \mathrm{~s}$ ). The analysis of the basic data is summarized in Table 7. 
Table 7. Basic Sample Data.

\begin{tabular}{|c|c|c|c|c|c|}
\hline Variable & Mean & Standard Deviation & Maximum Value & Minimum Value & Sample Size \\
\hline $\begin{array}{l}\text { Operating revenue } \\
\text { (TWD, } 1000 \mathrm{~s})\end{array}$ & $75,484,940$ & $165,361,564$ & $1,528,114,091$ & 189,890 & 837 \\
\hline $\begin{array}{l}\text { Employee salaries } \\
\text { (TWD, } 1000 \mathrm{~s})\end{array}$ & $6,757,311$ & $12,537,077$ & $144,986,247$ & 24,192 & 837 \\
\hline $\begin{array}{l}\text { Consumption of } \\
\text { raw materials } \\
(\mathrm{TWD}, 1000 \mathrm{~s})\end{array}$ & $46,743,297$ & $113,835,600$ & $1,397,979,509$ & 104,749 & 837 \\
\hline $\begin{array}{c}\text { Electricity } \\
\text { consumption } \\
\text { (TWD, } 1000 \mathrm{~s})\end{array}$ & $1,349,775$ & $3,264,405$ & $33,118,801$ & 1255 & 837 \\
\hline $\begin{array}{c}\text { Water } \\
\text { consumption } \\
\text { (cubic meters, } 1000 \\
\text { s) }\end{array}$ & 6834.3 & $21,771.8$ & $222,361.7$ & 6.1 & 837 \\
\hline $\begin{array}{c}\text { Outsourcing } \\
\text { expenditure (TWD, } \\
1000 \mathrm{~s})\end{array}$ & $2,790,517$ & $10,846,934$ & $168,487,386$ & 0 & 837 \\
\hline $\begin{array}{l}\text { Depreciation and } \\
\text { indirect taxes } \\
\text { (TWD, } 1000 \mathrm{~s})\end{array}$ & $13,862,444$ & $38,299,472$ & $428,513,664$ & 25,925 & 837 \\
\hline $\begin{array}{c}\text { Operating } \\
\text { expenses (TWD, } \\
1000 \mathrm{~s})\end{array}$ & $71,571,688$ & $156,830,784$ & $1,497,348,717$ & 196,871 & 837 \\
\hline
\end{tabular}

Note 1: Consumption of raw materials includes the consumption of raw materials, materials, material costs, and fuel costs.; Note 2: Depreciation and indirect taxes include depreciation, depletion and amortization, indirect taxes, and other operating expenses. Source: Compiled from [43].

\subsubsection{Regression Model}

The present study assesses the marginal benefits and marginal costs of industrial water use. Therefore, the present study chooses two methods for analysis: ordinary least squares (OLS), and quantile regression analysis. The quantile regression method was first proposed by [44] and later developed by $[17,45]$, and others, improving the theoretical basis of quantile regression estimation. Since the former represents the overall industry assessment results and the latter can represent the assessment results for specific sectors, the two assessment methods are complementary and can be used to complete the assessment results for the present study.

\subsubsection{Empirical Analysis of the Shadow Price of Industrial Water Use}

Based on the previous literature, this study uses the net marginal benefit of water use as the shadow value of industrial water use, calculated according to the following equation.

$$
\ln Y=a_{0}+b_{1} \ln X_{1}+b_{2} \ln X_{2}+b_{3} \ln X_{3}+e
$$

where $Y$ is total revenue (or output value) (TWD, $1000 \mathrm{~s}$ ); $X_{1}$ is employee salaries (TWD, $1000 \mathrm{~s}$ ); $X_{2}$ is the consumption of raw materials (TWD, $1000 \mathrm{~s}$ ), including consumption of raw materials, materials, material costs, and fuel costs; $X_{3}$ is water consumption (cubic meters, $1000 \mathrm{~s}) ; e$ is a residual term; $b_{i}(i=1,2,3)$ is an estimated parameter. Since all variables are logarithmic, the estimated parameters are elasticity. Elasticity is the percentage change in the dependent variable caused by a $1 \%$ change in an independent variable. For example, $b_{3}$ is the operating cost elasticity of water consumption, meaning that a $1 \%$ increase in water consumption would result in a $b_{3} \%$ increase in total operating revenue. 
The regression results are summarized in Table 8 . Table 8 shows that the OLS $R^{2}$ of 0.993 is very high. In addition, all of the regression coefficients show a significance level of $1 \%$. Of these, the operating revenue elasticity of water consumption $b_{3}$ is 0.046 , indicating that if water consumption increases by $1 \%$, a firm's operating revenue will increase by $0.046 \%$. The regression coefficient for water consumption is significant at $1 \%$ for all deciles, and the higher the decile, the high the regression coefficient for water consumption.

Table 8. Regression Results for Operating Revenue.

\begin{tabular}{cccccc}
\hline $\begin{array}{c}\text { Estimated } \\
\text { Parameters }\end{array}$ & $\mathbf{2 5 \%}$ & $\mathbf{5 0 \%}$ & $\mathbf{7 5 \%}$ & $\mathbf{9 0 \%}$ & OLS \\
\hline \multirow{2}{*}{$b_{0}$} & $0.826^{* * *}$ & $0.972^{* * *}$ & $1.099^{* * *}$ & $1.426^{* * *}$ & $1.122^{* * *}$ \\
& $(19.632)$ & $(19.260)$ & $(14.256)$ & $(11.164)$ & $(18.675)$ \\
\hline \multirow{2}{*}{$b_{1}$} & $0.196^{* * *}$ & $0.202^{* * *}$ & $0.205^{* * *}$ & $0.215^{* * *}$ & $0.222^{* * *}$ \\
& $(23.094)$ & $(25.319)$ & $(29.712)$ & $(20.823)$ & $(29.787)$ \\
\hline \multirow{2}{*}{$b_{2}$} & $0.792^{* * *}$ & $0.772^{* * *}$ & $0.763^{* * *}$ & $0.722^{* * *}$ & $0.739^{* * *}$ \\
\hline \multirow{2}{*}{$b_{3}$} & $(90.385)$ & $(92.048)$ & $(128.122)$ & $(81.975)$ & $(104.665)$ \\
\hline$R^{2}$ & $0.019^{* * *}$ & $0.033^{* * *}$ & $0.036^{* * *}$ & $0.067^{* * *}$ & $0.046^{* * *}$ \\
& $(4.591)$ & $(5.881)$ & $(6.105)$ & $(5.893)$ & $(8.228)$ \\
\hline
\end{tabular}

Note 1: The $t$-value of the elasticity coefficient is shown in parentheses.; Note 2: * Significant at $10 \%$; ** Significant at $5 \% ; * * *$ Significant at $1 \%$. Compiled by this study.

Based on the revenue elasticity of water consumption of 0.046 , substituting the average total operating revenue for the industry of TWD 75,484,940,000 and the average total water cost of industry of TWD 68,343,000, obtaining the marginal revenue of industrial water use of TWD 50.18/cubic meters. Since the price of tap water is TWD 10/cubic meters, the shadow price for industrial water is TWD 40.18/cubic meters (TWD 50.18/cubic meters -TWD 10/cubic meters). With revenue elasticity of 0.019 for companies with revenue at the $25 \%$ revenue interval, substituting the average total operating revenue for the industry of TWD 75,484,940,000 and the average total water cost of industry of TWD 68,343,000, obtaining the marginal revenue of industrial water use of TWD 21.0, and the shadow price of industrial water TWD 11/cubic meters (TWD 21/cubic meters-TWD 10/cubic meters). With revenue elasticity of 0.067 for companies with revenue at the $90 \%$ revenue interval, substituting the average total operating revenue for the industry of TWD 75,484,940,000 and the average total water cost of industry of TWD 68,343,000, obtaining the marginal revenue of industrial water use of TWD 74.0, and the shadow price of industrial water TWD 64/cubic meters (TWD 74/cubic meters-TWD 10/cubic meters).

\subsection{Assessing the Value of the Government's Water Supply Security Policy}

This section further discusses the losses from water shortages and assesses the losses caused to industry in the Taichung area in the context of climate change as an example. This serves as a basis for assessing the value of the government's stable water supply policy (such as proposals for water supply facilities and agricultural water transfer and compensation). The relevant content is described as follows:

\section{Losses from Water Shortages}

The value of water shortage losses is the economic and social deadweight loss caused by water shortage. Deadweight loss refers to the reduction in social welfare caused by water shortage, measured by the consumer's surplus and the producer's surplus, and is determined as the product of the amount of the water shortage and the net value of the resource (the difference between the shadow price of the water resource and the price of tap water). The shadow price of water represents the price a water user is willing to pay, less the cost of water, representing the net value to the water user. 


\section{Analysis of Water Shortage in the Taichung Area}

Based on the previous analysis, the water supply under climate change in Taichung between 2021 and 2031 is shown in Table 9 of this study. The content of Table 9 is as follows: Assuming the worst-case scenario, industrial water use in the Taichung area grows rapidly. This study measures the water demand of the industrial sector in a high growth scenario (worst-case scenario). Water consumption will increase from 548,500 cubic meters/day in 2021 to 751,800 cubic meters/day in 2031: a growth rate of 37.1\%. During the same period, the Futian Water Resource Recycling Center will be completed on schedule in 2023.with an initial water supply capacity was 61,000 cubic meters/day, which can be increased to 100,000 cubic meters/day by the year 2031. In addition, after deducting domestic water demand from water supply capacity in the Taichung area, the amount of water available for industrial use increases from 302,700 cubic meters/day in 2021 to 416,600 tons/day in 2021.

Table 9. Estimate of Shortage in Industrial Water in Taichung under Climate Change.

\begin{tabular}{|c|c|c|c|c|c|c|c|c|c|c|c|c|}
\hline Target Year & 2021 & 2022 & 2023 & 2024 & 2025 & 2026 & 2027 & 2028 & 2029 & 2030 & 2031 & \\
\hline $\begin{array}{l}\text { Industrial water demand } \\
\text { (High growth) }\end{array}$ & 54.85 & 56.88 & 58.92 & 60.95 & 62.99 & 65.02 & 67.05 & 69.08 & 71.12 & 73.15 & 75.18 & \\
\hline $\begin{array}{c}\text { Futian Water Resource } \\
\text { Recycling Center } \\
\text { Water supply capacity }\end{array}$ & 0.00 & 0.00 & 6.10 & 6.10 & 6.10 & 9.65 & 9.65 & 9.65 & 9.65 & 9.65 & 10.00 & \\
\hline $\begin{array}{l}\text { Public water facilities } \\
\text { Water supply capacity } \\
\text { (Deduct domestic water } \\
\text { demand) }\end{array}$ & 30.27 & 30.33 & 30.39 & 30.45 & 30.51 & 55.57 & 55.60 & 54.03 & 51.41 & 48.79 & 46.16 & Total \\
\hline Industrial water shortage & $(24.58)$ & $(26.55)$ & (22.43) & $(24.40)$ & $(26.38)$ & 0.20 & $(1.80)$ & $(5.40)$ & $(10.06)$ & $(14.71)$ & $(19.02)$ & (175.13) \\
\hline
\end{tabular}

Unit: 10,000 cubic meters/day; Note: Figures in parentheses indicate water shortage. Source: [27], Compiled by this study.

Based on the above, under the impact of climate change, it is estimated that the shortage of water for industrial use in the Taichung area will increase to 175,300 cubic meters/day between 2021 and 2031.

3. Industrial Water Shortage Losses and Policy Value Assessment for Taichung Area

(1) Scenario construction

The scenarios for this study are detailed in Table 10. There are two different scenarios.

Table 10. Scenario Settings.

\begin{tabular}{|c|c|}
\hline Scenario & Content \\
\hline Scenario 1: Base scenario & $\begin{array}{l}\text { 1. Probability of water shortage risk in a dry year: } 100 \% \text { (worst-case scenario) } \\
\text { 2. Already planned water supply facilities (Futian Water Resource Recycling } \\
\text { Center and other public water supply facilities projects etc.) }\end{array}$ \\
\hline Scenario 2: No Water Shortage Scenario & $\begin{array}{l}\text { 1. Probability of water shortage risk in a dry year: } 100 \% \text { (worst-case scenario) } \\
\text { 2. No water shortage: transfer of water from agriculture }\end{array}$ \\
\hline Shadow price & $\begin{array}{l}\text { 1. TWD 64/cubic meters (high scenario) } \\
\text { 2. TWD } 40.18 / \text { cubic meters (medium scenario) }\end{array}$ \\
\hline
\end{tabular}

\section{- Scenario 1:}

As the baseline scenario, i.e., the water shortage scenario, assuming (1) probability of water shortage risk in a dry year: $100 \%$ (worst-case scenario); (2) already planned water supply facilities (Futian Water Resource Recycling Center and other public water supply facilities projects, etc.). 


\section{- Scenario 2:}

No water shortage scenario, assuming (1) probability of water shortage risk in a dry year in a dry year: $100 \%$ (worst case scenario) and (2) transfer of water from agriculture.

The shadow price was assessed at TWD 64/cubic meters (high scenario) and TWD 40.18/cubic meters (medium scenario).

(2) Assessment of losses from water shortages. This study assumes zero elasticity of demand for water, i.e., the demand curve is vertical, and also assumes a fixed shadow price.

I. Shadow price TWD 40.18 / cubic meters (medium scenario)

The cumulative value of losses from water shortages between 2021 and 2031 is as follows:

1.7513 million cubic meters/day $\times 365$ days $\times$ TWD 40.18/ cubic meters $=$ TWD 25.684 billion. It is not easy to estimate the number of days of water shortage. Therefore, to simplify the analysis, water shortage was estimated on an annual basis, which is a limitation of this study.

II. Shadow price TWD 64/cubic meters (high scenario)

The cumulative value of losses from water shortages between 2021 and 2031 is as follows: 1.7513 million cubic meters $/$ day $\times 365$ days $\times$ TWD $64 /$ cubic meters $=$ TWD 40.91 billion

III. Assessing the Value of the Water Supply Security Policy

Assuming the government transfer about 1.7513 million cubic meters/day of water for agricultural use (2021-2031), and assuming that the shadow price of agricultural water is TWD 15.3/cubic meters (the highest price in the literature), the cumulative cost of transferring water for agricultural use (2021-2031) is TWD 9.78 billion.

Deducting TWD 9.78 billion from the previous value of losses due to water shortages, the cumulative value (2021-2031) of the water resources policy to transfer agricultural water to achieve water supply security is about TWD 15.904 billion (shadow price of TWD 40.18/cubic meters)-TWD 31.13 billion (shadow price of TWD 64/cubic meters).

\section{Conclusions}

The present study refers to the multi-criteria (including water supply security) water supply portfolio model developed by [1], using water resources data and proposals for water supply facilities from central Taiwan, and a worst-case scenario under extreme climate (dry scenario) to evaluate and plan a feasible water supply portfolio for central Taiwan. The study found that under the climate change scenario, the Miaoli and Nantou areas are relatively free of water supply problems in 2031. Due to its diverse water supply resources, the Taichung area has greater flexibility. Due to the severe impact of climate change and restrictions on groundwater extraction, the water supply situation in the Yunlin and Changhua area is fragile. The results of the present study have important policy implications, which is one of the main contributions of the study.

The present study first uses industrial water as an example to assess the shadow price of water resources and assess the cost of water shortage during dry periods under climate change in central Taiwan as a basis for assessing the value of the water supply security policy and a reference for water supply portfolio planning. The finding of the average marginal benefits of industrial water use is about TWD 50.18/ton (including the benefits of government water supply facilities), which is much higher than the price of tap water. This provides a theoretical basis for the government to consider increasing the price of tap water. The cumulative value (2021-2031) of the water resources policy to reallocate agricultural water to achieve water supply security is approximately TWD 15.904-31.130 billion. The shadow price of industrial water is about TWD 40.18/cubic meters. The shadow price of agricultural water is about TWD 15.3/cubic meters. Therefore, the price for agricultural water reallocation of between TWD 15.3/cubic meters and TWD 40.18/ cubic meters represents a rational policy. This study provides the theoretical basis for the rationality of the government's current agricultural water transfer compensation policy, which is the second major contribution of this study. 
Demand-side management is another important issue in water supply security. This study considers the government's target of achieving a water supply of 20 billion cubic meters by 2031 and attaining water supply security across all periods but has not considered demand-side management. In the future, water conservation requirements can be planned for each period on the basis of a "supply determined model". For example, the water conservation can be assigned as variables which describe the amount of water that can be saved and the related cost of water conservation measures. The results can be used to determine the intensity of measures by policy-makers.

The study uses central Taiwan as an example to assess the value of water supply security policy. The same method can also be applied to other regions. The present study assesses the shadow value of industrial water use using marginal benefits. However, there are many ways to measure shadow value. This is one of the limitations of the study.

Author Contributions: Conceptualization, Y.-C.H.; Methodology, C.-M.L.; Software, Y.-C.H. and C.-M.L.; Validation, C.-M.L. and Y.-R.H.; Formal analysis, Y.-C.H.; Investigation, Y.-C.H. and Y.-R.H.; Resources, Y.-C.H.; Data curation, Y.-C.H.; Writing-original draft preparation, Y.-C.H.; Writingreview and editing, C.-M.L. and Y.-R.H.; Visualization, Y.-C.H. and Y.-R.H.; Supervision, C.-M.L.; Project administration, C.-M.L.; Funding acquisition, Y.-C.H. and C.-M.L. All authors have read and agreed to the published version of the manuscript.

Funding: This research was partially funded by Water Resource Agency, Ministry of Economic Affairs, Taiwan and the grant number is MOST107-3113-F-042A-001.

Institutional Review Board Statement: The study was conducted according to the guidelines.

Informed Consent Statement: Informed consent was obtained from all subjects involved in the study.

Conflicts of Interest: The authors declare no conflict of interest.

\section{Appendix A}

The current Hamiltonian and Lagrangian functions for the optimal control problem are shown in Equations (A1) and (A2): (subscript $t$ is omitted).

$$
\begin{gathered}
H_{c}=\sum_{i=1}^{3} T C_{i}-\sum_{i=1}^{3} m_{i}\left(I_{i}-\delta_{i} K_{i}\right) \\
L_{c}=H_{c}-\theta_{1}\left(\sum_{i=1}^{3} Q_{i}-\bar{Q}\right)-\theta_{2}\left(\bar{E}_{T}-\sum_{t=0}^{T} \sum_{i=1}^{3} E_{i t}\right)-\theta_{3}\left(\bar{Q}_{T}-\sum_{i=1}^{3} Q_{i T}\right)
\end{gathered}
$$

where $m_{i}$ is the co-state variable for water resources capital, or shadow price, and $n$ is the covariate of abatement capital. $\theta_{1} \sim \theta_{3}$ are the Lagrangian multipliers for water security, carbon dioxide emission targets, and total water supply limits, respectively. Assuming $I_{i}>0$, the maximization condition is as follows $(\forall i=1 \sim 3)$ :

$$
\begin{gathered}
\frac{\partial L_{c}}{\partial I_{c}}=0 \Rightarrow P_{I i}=m_{i} \\
\frac{\partial L_{c}}{\partial F_{i}}=0 \Rightarrow P_{F i}+\phi_{i} \frac{\partial Q_{i}}{\partial F_{i}}+P_{e i} e_{0 i}-\theta_{i} \frac{\partial Q_{i}}{\partial F_{i}}+\theta_{2} \sum_{t=0}^{T} e_{0 i}=0 \\
\Rightarrow \frac{\partial Q_{i}}{\partial F_{i}}=\frac{P_{F i}+P_{e i} e_{0 i}-\theta_{2} \sum_{t=0}^{T} e_{0 i}}{\theta_{i}-\phi_{i}} \\
\frac{\partial L_{c}}{\partial A_{i}}=0 \Rightarrow P_{A i}-P_{e i}+\theta_{2} \sum_{t=0}^{T}(-1)=0 \\
\Rightarrow P_{A i}=P_{e i}+\theta_{2} T
\end{gathered}
$$




$$
\begin{gathered}
\dot{m}_{i}=-\frac{\partial L_{c}}{\partial K_{i}}+\rho m_{i}=-\phi_{i} \frac{\partial Q_{i}}{\partial K_{i}}-\delta m_{i}+\theta_{i} \frac{\partial Q_{i}}{\partial K_{i}}+\rho m_{i} \\
=\left(\theta_{i}-\phi_{i}\right) \frac{\partial Q_{i}}{\partial K_{i}}-\left(\delta_{i}-\rho\right) m_{i} \\
\theta_{1} \frac{\partial L_{c}}{\partial \theta_{1}}=0 \Rightarrow \theta_{1}\left(\sum_{i=1}^{3} Q_{i}-\bar{Q}\right)=0 \\
\theta_{2} \frac{\partial L_{c}}{\partial \theta_{2}}=0 \Rightarrow \theta_{2}\left(\bar{E}_{T}-\sum_{t=0}^{T} \sum_{i=1}^{3} E_{i t}\right)=0 \\
\theta_{3} \frac{\partial L_{c}}{\partial \theta_{3}}=0 \Rightarrow \theta_{3}\left(\bar{Q}_{T} \sum_{i=1}^{3} Q_{i T}\right)=0
\end{gathered}
$$

Equations (A3)-(A5) are the optimal investment in water resources, raw water input, and emissions abatement, respectively. Equations (A7)-(A9) represent water resources security, carbon abatement targets, and final water production targets, respectively.

Assuming the economy is in a steady state $\left(\dot{m}_{i}=0\right)$, then Equation (A6) can be adjusted as follows:

$$
\frac{\partial Q_{i}}{\partial K_{i}}=\frac{\left(\delta_{i}-\rho\right) m_{i}}{\theta_{i}-\phi_{i}}
$$

Substituting Equation (A3) into Equation (A10) yields:

$$
\frac{\partial Q_{i}}{\partial K_{i}}=\frac{P_{I i}\left(\delta_{i}-\rho\right)}{\theta_{i}-\phi_{i}}
$$

The economic meaning of the above equation is as follows: The optimal level of investment in water resources is determined as where the marginal output $\left(\partial Q_{i} / \partial K_{i}\right)$ equals the marginal real cost of investment, where $P_{I i}\left(\delta_{i}-\rho\right)$ is the net depreciation cost of investment in water supply facilities, equal to the depreciation costs $\left(P_{I i} \delta_{i}\right)$ minus interest costs $\left(P_{I i} \rho\right) ;\left(\theta_{1}-\phi_{i}\right)$ is a deflator that converts nominal costs into real costs.

Equation (A5) shows that the optimal level of abatement is determined as where the marginal cost of abatement $\left(P_{A i}\right)()$ equals the marginal benefit of abatement $\left(P_{e i}+\theta_{2} T\right)$. The marginal benefit of abatement includes emissions cost savings $\left(P_{e i}\right)$ and the value of obtaining the abatement target $\left(\theta_{2} T\right)$. Given that this study assumes $e_{0 i}$ is fixed, $\theta_{2} \sum_{t=0}^{T} e_{0 i}=$ $T \theta_{2} e_{0 i}$. From Equation (A6), we find $\theta_{2}=\left(P_{A i}-P_{e i}\right) / T$, producing the equation for optimal fuel level when substituted into (A5):

$$
\frac{\partial Q_{i}}{\partial F_{i}}=\frac{P_{F i}+P_{A i} e_{0 i}}{\theta_{i}-\phi_{i}}
$$

The economic meaning of (A12) is as follows: The optimal raw water input level for water production technology consistent with sustainable water resources is determined as where marginal production $\left(\partial Q_{i} / \partial F_{i}\right)$ equals the actual raw water input cost $\left(\left(P_{F i}+P_{A i} e_{0 i}\right) /\left(\theta_{i}-\phi_{i}\right)\right)$. Where, the actual raw water input cost includes raw water input $\operatorname{cost}\left(P_{F i}\right)$ and carbon dioxide emission $\operatorname{cost}\left(P_{A i} e_{0 i}\right) ;\left(\theta_{i}-\phi_{i}\right)$ is a deflator that converts nominal costs into real costs. From Equation (A12), abatement activities will consider the price of carbon. The optimal amount of raw water input is affected by the carbon emission factor, which is in turn affected by the carbon price $\left(P_{e i}\right)$.

In order to further explore the water supply ratio, the present study assumed that the water supply amount $\left(Q_{i t}\right)$ is a Cobb-Douglas (C-D) function, with a constant return to scale (CRS), i.e., $Q_{i t}=\omega_{i t} K_{i t}^{\gamma} F_{i t}^{1-\gamma}$, where, $\gamma$ is a fixed parameter, and $0 \leq \gamma \leq 1$, $\omega_{i t}$ is the water production capacity factor (Note 8 ). For surface water production capacity factor $\left(\omega_{i t}\right)$, this study uses the proportion of rainfall that cannot be converted into usable water resources $\left(\alpha_{1 t}\right)$, such as evapotranspiration and infiltration. The impacts of climate change (decreased rainfall or more concentrated rainfall) are represented by factors such as the ratio $\left(\beta_{1}\right)$ of surface water that can be collected and the ratio $(\mu)$ of ecological base 
flow, reflecting that water production is affected by hydrological conditions and climate change. For groundwater production capacity factor $\left(\omega_{2 t}\right)$, this study uses the proportion of total infiltration that cannot be converted into usable groundwater resources $\left(\alpha_{2 t}\right)$, such as boundary outflow. The impacts of climate change (decreased rainfall or more concentrated rainfall) are reflected in the lower proportion of groundwater that is retained $\left(\beta_{2}\right)$ and the groundwater recharge ratio $(\eta)$, reflecting that water production is affected by hydrological conditions and climate change. In addition, because the water production capacity of seawater desalination facilities is hardly affected by changes in hydrological conditions, the present study assumes that its water production capacity factor is independent of rainfall variation and climate change, i.e., $\omega_{3 t}=1$.

The present study divides Equation (A11) by Equation (A12), producing the optimal water resources capital and amount of raw water decision-making equation (subscript $t$ is omitted).

$$
\frac{\partial Q_{i} / \partial K_{i}}{\partial Q_{i} / \partial F_{i}}=\frac{\gamma}{1-\gamma} \frac{F_{i}}{K_{i}}=M R T S_{i}=M C_{i}=\frac{P_{I i}\left(\delta_{i}-\rho\right)}{P_{F i}+P_{A i} e_{0 i}}
$$

Where $M R T S_{i}$ is the marginal rate of technology substitution for water supply technology $i ; M C_{i}$ is the relative raw water cost and real capital cost for water resource technology $i$ Equation (A13) is optimal decision-making for production factors in classical microeconomics. When $k_{i}=F_{i} / K_{i}$, then, based on the C-D production function, the supply capacity function for each water supply facility can be obtained as follows.

$$
\begin{aligned}
& \frac{Q_{1}}{K_{1}}=\omega_{1} k_{1}^{1-\gamma}=\left(1-\alpha_{1}\right)\left(1-\beta_{1}\right)(1-\mu)\left(\frac{1-\gamma}{\gamma}\right)^{1-\gamma}\left(\frac{P_{I 1}\left(\delta_{1}-\rho\right)}{P_{F 1}+P_{A 1} e_{01}}\right)^{1-\gamma} \\
& \frac{Q_{2}}{K_{2}}=\omega_{2} k_{2}^{1-\gamma}=\left(1-\alpha_{2}\right)\left(1-\beta_{2}\right)(1-\eta)\left(\frac{1-\gamma}{\gamma}\right)^{1-\gamma}\left(\frac{P_{I 2}\left(\delta_{2}-\rho\right)}{P_{F 2}+P_{A 2} e_{02}}\right)^{1-\gamma} \\
& \frac{Q_{3}}{K_{3}}=\omega_{3} k_{3}^{1-\gamma}=\left(\frac{1-\gamma}{\gamma}\right)^{1-\gamma}\left(\frac{P_{I 3}\left(\delta_{3}-\rho\right)}{P_{F 3}+P_{A 3} e_{03}}\right)^{1-\gamma}
\end{aligned}
$$

Through Equation (A14) to (A16), we can estimate the optimal water production and allocation of each water resource. From observation of the above equations, we find that the production capacity function of each water supply facility is affected by the technical parameters of water resources $(\gamma)$, net depreciation cost of investment in water supply facilities $\left(P_{I i}\left(\delta_{i}-\rho\right)\right)$, raw water input costs $\left(P_{F i}\right)$, emission abatement costs $\left(P_{A i}\right)$, the carbon emission coefficient for raw water $\left(e_{0 i}\right)$, the ratio that cannot be converted into usable water resources $\left(\alpha_{i}\right)$, the decline in the total volume that can be extracted due to the impact of climate change $\left(\beta_{i}\right)$, the ecological base flow ratio $(\mu)$, and the ratio of safe yield of groundwater $(\eta)$.

\section{References}

1. Intergovernmental Panel on Climate Change. Climate Change 2014: Synthesis Report; IPCC Press: Geneva, Switzerland, 2014.

2. $\mathrm{Xu}, \mathrm{C}$. Modelling the effects of climate change on water resources in central Sweden. Water Resour. Manag. 2000, 14, 177-189. [CrossRef]

3. Kundzewicz, Z.W.; Mata, L.J.; Arnell, N.W.; Döll, P.; Jimenez, B.; Miller, K.; Oki, T.; Şen, Z.; Shiklomanov, I. The implications of projected climate change for freshwater resources and their management. Hydrol. Sci. J. 2008, 53, 3-10. [CrossRef]

4. Pahl-Wostl, C. Transitions towards adaptive management of water facing climate and global change. Water Resour. Manag. 2007, 21, 49-62. [CrossRef]

5. Dessai, S.; Hulme, M. Assessing the robustness of adaptation decisions to climate change uncertainties: A case study on water resources management in the East of England. Glob. Environ. Chang. 2007, 17, 59-72. [CrossRef]

6. Mulangu, F.; Kraybill, D. A cost-benefit analysis of improved irrigation when faced with the risks of climate change on Mount Kilimanjaro. Water Resour. Econ. 2015, 10, 31-44. [CrossRef]

7. Draper, A.J.; Jenkins, M.W.; Kirby, K.W.; Lund, J.R.; Howitt, R.E. Economic-Engineering Optimization for California Water Management. J. Water Resour. Plan. Manag. 2003, 129, 155-164. [CrossRef]

8. Harou, J.J.; Pulido-Velazquez, M.; Rosenberg, D.E.; Medellín-Azuara, J.; Lund, H.R.E. Hydro-economic models: Concepts, design, applications, and future prospects. J. Hydrol. 2009, 375, 627-643. [CrossRef] 
9. Borgomeo, E.; Mortazavi-Naeini, M.; Hall, J.W.; O'Sullivan, M.J.; Watson, T. Trading-off tolerable risk with climate change adaptation costs in water supply systems. Water Resour. Res. 2016, 52, 622-643. [CrossRef]

10. Huang, Y.C.; Lee, C.M. Designing an Optimal Water Supply Portfolio for Taiwan under the Impact of Climate Change: Case Study of the Penghu Area. J. Hydrol. 2019, 573, 235-245. [CrossRef]

11. Herrington, P. Pricing of Water Services; OECD Press: Paris, France, 1987.

12. Hotelling, H. The Economics of Exhaustible Resource. J. Political Econ. 1931, 29, 137-175. [CrossRef]

13. Burt, R.O. Optimal Resource Use over Time with an Application to Groundwater. Manag. Sci. 1964, 11, 80-93. [CrossRef]

14. Brown, G., Jr.; Deacon, R. Economic optimization of a single-cell aquifer. Water Resour. Res. 1972, 8, 557-564. [CrossRef]

15. Gisser, M.; Sanchez, D.A. Competition versus optimal control in groundwater pumping. Water Resour. Res. 1980, 16, 638-642. [CrossRef]

16. Negri, D.H. The common property aquifer as a differential game. Water Resour. Res. 1989, 25, 9-15. [CrossRef]

17. Kim, T.-H.; Muller, C. Two-stage quantile regression when the first stage is based on quantile regression. Econom. J. 2004, 7, 218-231. [CrossRef]

18. Provencher, B.; Burt, O. The externalities associated with the common property exploitation of groundwater. J. Environ. Econ. Manag. 1993, 24, 139-158. [CrossRef]

19. Knapp, K.C.; Olson, L.J. The economics of conjunctive groundwater management with stochastic surface supplies. J. Environ. Econ. Manag. 1995, 28, 340-356. [CrossRef]

20. Tsur, Y.; Zemel, A. Uncertainty and irreversibility in groundwater resource management. J. Environ. Econ. Manag. 1995, 29, 149-161. [CrossRef]

21. Dachraoui, K.; Harchaoui, T.M. Water Use, Shadow Prices and the Canadian Business Sector Productivity Performance. Stat. Can. 2004, 026, 1-28. [CrossRef]

22. Ziolkowska, J.R. Evaluating the Shadow Price of Water for Irrigation-A Case of the High Plain. In Proceedings of the 2014 AAEA Annual Meeting, Minneapolis, MN, USA, 27-29 July 2014.

23. Williams, R.B.; Al-Hmoud, R.; Segarra, E.; Mitchell, D. An Estimate of the Shadow Price of Water in the Southern Ogallala Aquifer. J. Water Resour. Prot. 2017, 9, 289-304. [CrossRef]

24. Veninga, W. The Shadow Price of Fossil Groundwater; Wageningen University: Wageningen, The Netherlands, 2017.

25. Huang, C.H.; Lin, S.H. The Economic Analysis of Water Right and Water Right Price; National Tsing Hua University: Hsinchu, Taiwan, 1995. Working Paper. (In Chinnese)

26. Lee, C.M.; Huang, C.H. Water Use and Price Dynamics of Water Right Permit under Groundwater Trading System. Taiwan J. Appl. Econ. 2000, 67, 71-97. (In Chinese)

27. Water Resources Agency. Basic Plan for Water Resources Managers in Central Taiwan Region; Water Resources Agency: Taichung, Taiwan, 2016. (In Chinese)

28. Water Resources Planning Institute. Economic Benefit Cost Analyses and Evaluation for Water Resource Development Project; Water Resources Planning Institute: Taichung, Taiwan, 2013. (In Chinese)

29. Water Resources Agency. Economic Benefit Analysis of Reservoir Watershed Conservation; Water Resources Agency: Taichung, Taiwan, 2017. (In Chinese)

30. Water Resources Planning Institute. Review Report of Feasibility Planning for the Tianhuahu Reservoir; Water Resources Planning Institute: Taichung, Taiwan, 2011. (In Chinese)

31. Taiwan Water Corporation. The Statistical Yearbook of Taiwan Water Corporation; Taiwan Water Corporation: Taichung, Taiwan, 2017. (In Chinese)

32. Huang, Y.C.; Lee, C.M. The Study of Optimal Water Supply Portfolio for Climate Change Impact in Taiwan-The Case Study of Penghu Area. Taiwan. Agric. Econ. Rev. 2017, 23, 41-72. (In Chinese)

33. Water Resources Agency. Construction Plan Joint Water Source Utilization Project of Da'an and Dajia Rivers (Version approved by Executive Yuan); Water Resources Agency: Taichung, Taiwan, 2011. (In Chinese)

34. Construction and Planning Agency. Feasibility Assessment for Recycling of Discharge Water by the Futian Water Resource Recycling Center and Subsequent Commissioning of Technical Services-Phase III Results Report and Assessment of Benefits of Turnkey Contracting (Final Version); Construction and Planning Agency: Taipei, Taiwan, 2016. (In Chinese)

35. Ministry of Economic Affairs. Forward-looking Infrastructure Development Program-Water Environment Infrastructure-Wu River Niaozuitan Artificial Lake Construction Project (Final version); Ministry of Economic Affairs: Taipei, Taiwan, 2015. (In Chinese)

36. Water Resources Agency. Environmental Impact Assessment Report of the Hushan and Hunan Reservoir Project; Water Resources Agency: Taichung, Taiwan, 2000. (In Chinese)

37. Central Region Water Resources Office. Hushan Reservoir Operations and Management 2016-Report on Outcome of Water Resources Allocation 2016; Central Region Water Resources Office: Taichung, Taiwan, 2017. (In Chinese)

38. Central Region Water Resources Office. Hushan Reservoir Webpage. Available online: http://www.wracb.gov.tw/mp.asp?mp= 15 (accessed on 2 December 2020).

39. Water Resources Agency. Preliminary Student on Carbon Footprint and Carbon Reduction Strategy; Water Resources Agency: Taichung, Taiwan, 2010. (In Chinese)

40. Water Resources Planning Institute. Tianhuahu Reservoir Plan (3)-Assessment of Energy Conservation and Carbon Reduction Based on the Reservoir Life Cycle; Water Resources Planning Institute: Taichung, Taiwan, 2010. (In Chinese) 
41. Water Resources Planning Institute. Study on Carbon Management System for Water Resources Projects-General Report; Water Resources Planning Institute: Taichung, Taiwan, 2015. (In Chinese)

42. Water Resources Agency. Wu River Niaozuitan Artificial Lake Construction Project-Project-Environmental Impact Statement (Final Version); Water Resources Agency: Taichung, Taiwan, 2013. (In Chinese)

43. Ministry of Economic Affairs. Factory Operation Census Report; Ministry of Economic Affairs: Taipei, Taiwan, 2013. (In Chinese)

44. Koenker, R.; Bassett, G., Jr. Regression quantiles. Econometrica 1978, 46, 33-50. [CrossRef]

45. Construction and Planning Agency. Plan for Recycling of Discharge Water by the Futian Water Resource Recycling Center (Approved Version); Construction and Planning Agency: Taipei, Taiwan, 2017. (In Chinese) 